\title{
Implementation of Transcendental-Based Juvenile Criminal Sanctions
}

\author{
Agatha Jumiati \\ Universitas Slamet Riyadi \\ AgathaJumiati@unisri.ac.id
}

DOI: dx.doi.org/10.23917/jtl.v3i1.15218

\begin{tabular}{|c|c|}
\hline Submission & ABSTRACT \\
\hline Track: & The development of law in Indonesia is carried out \\
\hline $\begin{array}{l}\text { Received: } \\
20 \text { July } 2021\end{array}$ & $\begin{array}{l}\text { based on the noble values contained in the precepts } \\
\text { of Pancasila. These noble values are actually an }\end{array}$ \\
\hline $\begin{array}{l}\text { Final Revision: } \\
29 \text { September } 2021\end{array}$ & $\begin{array}{l}\text { Transcendental thought is an alternative to answer } \\
\text { the failure of the positivistic view in solving legal }\end{array}$ \\
\hline $\begin{array}{l}\text { Available online: } \\
30 \text { September } 2021\end{array}$ & $\begin{array}{l}\text { problems in society. Regarding the implementation } \\
\text { of juvenile criminal sanctions which commit criminal } \\
\text { acts as regulated by Law number } 11 \text { of } 2012\end{array}$ \\
\hline $\begin{array}{l}\text { Corresponding } \\
\text { Author: } \\
\text { Agatha Jumiati } \\
\text { AgathaJumiati@unisri.ac.id }\end{array}$ & $\begin{array}{l}\text { concerning the Juvenile Criminal Justice System, it } \\
\text { turns out that in its regulation it has implemented } \\
\text { transcendental values by placing child as noble } \\
\text { creatures created by God who must always be guided } \\
\text { and protected even though they have been or have } \\
\text { committed a mistake or crime. Regulations on } \\
\text { diversion, restorative justice, strengthening the role } \\
\text { of the correctional center and the types of crimes that } \\
\text { are humane are evidence that the implementation of } \\
\text { juvenile criminal sanctions in Indonesia has } \\
\text { contained transcendental values. }\end{array}$ \\
\hline
\end{tabular}

Keywords: Implementation of Sanctions, Transcendental, Juvenile Crime

\section{INTRODUCTION}

Indonesia as a country that adheres to the rule of law is naturally obliged to conduct the development in the field of law in order to lead to an orderly, peaceful, just and prosperous society. The context of legal development must of course be interpreted as an embodiment of a deep thought about how national law is formed, 
implemented/used to regulate people's lives, and then to be enforced.

Viewing from the aspect of the structure of the formation of law, it is very clear that the meaning of law will be perceived as a written form of law, namely statutory regulations. Law is legislation formed by an agency that has the authority, accompanied by sanctions to regulate the social life of the community. Law which has a juridical ${ }^{3}$ meaning is the law determined by the government of a country, namely the constitution. Law in the true sense (properly so called) is law that originates from the state and or is confirmed by the state. Other laws can still be called law, (improperly so called) but not in the true juridical sense.

Development in the field of law must be based on the foundation of the ideals contained in the view of life, awareness and noble moral ideals which include the psychological atmosphere and character of Indonesian nation found in Pancasila and the 1945 Indonesian Constitution. According to Satjipto Rahardjo, law as the embodiment of values implies that its presence is to protect and promote the values upheld by the people (2002: 60). Thus, the law is not a technical institution that is morally empty and morally sterile.

Law as a regulation of human actions made by legitimate power, not only in the form of decisions but also in its implementation in accordance with the ideology of the nation concerned, as an institutional protector of the nation, based on natural law (Ali, 2015: 74). It means that the recognition of human dignity as a person with the possibility for self-development (Setiardja, 1990: 154). Because Indonesia has chosen a state of law (welfare state) as a form of state, every action and consequence taken by the parties must be based on and resolved according to law (Lubis, et al., 1995: 352). Indirectly, all things will be based on Pancasila as the nation's ideology.

Pancasila as stated in the preamble of the 1945 Indonesian Constitution is an intact and unified whole of the five precepts, they are Belief in One God, Just and Civilized Humanity, Indonesian Unity, Democracy Led by Wisdom in Deliberation/Representation, and Social Justice for All Indonesian people. This means that the development of national law is essentially building concepts of order that are oriented to the values of Pancasila, namely:

1. Religious morals (divinity);

2. Humanistic (humanity);

3. Nationalistic/unity (nationality); 
4. Democracy (populist);

5. Social justice. (Ali, 2015: 79)

The development of national law that is oriented towards religious moral values can be understood that the noble moral values that have been grounded in Indonesia must be used as the basis for formulating national legal policies. On the other hand, the teachings of Islam that have been practiced in social life by the majority of the Indonesian population have lasted for centuries. This means that the noble moral values that are firmly embedded and settled in Indonesia are complemented by transcendent religious values, namely the teachings of Islam (Noer, 1980: 4). There is nothing in Pancasila that contradicts the teachings of Islam. In fact, by implementing the values of Pancasila in the life of the nation and state, it can be understood as a form of practicing Islamic teachings in the Indonesian context (Karim, 2004: 46-50).

According to Arief, the renewal of national law must be adapted to the characteristics of society and legal sources in Indonesia. The characteristics of Indonesian society are more monodualistic and pluralistic. Sources of national law are oriented to the legal values that live in society, namely from the values of customary law and religious law (Arief, 2003: 43-44).

In legal renewal, it is necessary and important to implement transcendental thought. The failure of the positivistic legal school in unraveling legal problems in society encourages to seek and find the backing of legal thought that is able to answer challenges or needs. Postpositivistic legal thought presents the idea that law cannot be separated from morals, ethics and religious values so that the law is able to achieve the goal of realizing justice and welfare for mankind.

\section{PROBLEM STATEMENT}

"Has the implementation of juvenile criminal sanctions implemented transcendental values?”

\section{DISCUSSION}

\section{Implementation of Juvenile Criminal Sanctions According to Law Number 11 of 2012}

Children are not miniature adults who are mentally mature and mature mind. They have not been able to make decisions for themselves, are not yet responsible, are not aware of their roles, and control their minds, hearts and emotions in a balanced way. It is too hard for children to bear the responsibility of a fatal accident, while an adult thinks before acting, then feels.

Children by nature still have reasoning power that is not yet good enough 
to distinguish between good and bad things. Crimes committed by children in general are a process of imitating or being influenced by persuasion from adults. The formal criminal justice system which ultimately places children in prison status certainly brings considerable consequences in terms of children growth and development. The process of punishment given to children through the formal criminal justice system by placing children in prison did not succeed in deterring the children and becoming a better person to support the process of growth and development. Prison often makes children more professional in committing crimes.

Law No. 11 of 2012 concerning the Juvenile Criminal Justice System brought progress to the protection of children. As Article 1 of Law no. 11 of 2012 states that the juvenile criminal justice system is the entire process of resolving cases of childremr in conflict with the law, starting from the investigation stage to the stage of mentoring after serving a crime. The juvenile criminal justice system (Article 2) is implemented based on the following systems: protection, justice, non-discrimination, respect for children's opinions, child survival and development, children development and guidance, proportionality, deprivation of liberty and punishment as a final measure, avoidance of retaliation.

According to Law no. 11 of 2012 concerning the Juvenile Criminal Justice System, Article 69 paragraph (2), Children who are not yet 14 (fourteen) years old can only be subject to action. Meanwhile, Article 70 states that the lightness of the act, the children's personal conditions, or the circumstances at the time the act was committed or what happened later can be used as the basis for judge's consideration not to impose a sentence or impose an action taking into account the aspects of justice and humanity.

Law No. 11 of 2012 concerning the Juvenile Criminal Justice System does not follow the provisions of criminal sanctions contained in Article 10 of the Criminal Code but makes separate sanctions, which are contained in Articles 71 to 81. Punishments that can be imposed on children who commit criminal acts according to Law No. 11 of 2012 include: Basic Criminal and Additional Criminal.

The basic crimes consist of: 

a. warning punishment;
b. criminal with conditions:
c. coaching outside the institution
d. Society service; or Supervision
e. Work training;
f. Coaching with the institution or prison
While additional criminals consist of:

a. deprivation of profits derived from criminal acts; or

b. fulfillment of customary obligations.

Criminals imposed on children are prohibited from violating the dignity of the children. Further provisions regarding the form and procedure for the implementation of the crime as referred to in paragraph (1), paragraph (2), and paragraph (3) are regulated by Government Regulation Number 65 of 2015 concerning Guidelines for the Implementation of Diversion and Handling of Children who are not yet 12 (Twelve) years old.

The regulation on action sanctions in Law no. 11 of 2012 concerning the Juvenile Criminal Justice System is regulated in Article 82, consisting of:
a. return to parent/student guardian;
b. handover to someone;
C. treatment in psychiatric hospitals;
d. treatment at LPKS (Social Welfare Organization);
e. the obligation to attend formal education and/or training held by the government or private institutions;
f. revocation of driving license; and/or
g. reparation for the crime.

The enactment of Law No. 11 of 2012 concerning the Juvenile Criminal Justice System (UU SPPA) gives a very big hope for the Ministry of Law and Human Rights (c.q. Directorate General of Corrections) to immediately strengthen the existence of Correctional Centers in the judicial process. This is none other than because the Juvenile Criminal Justice System Law provides a very large role for the Correctional Center in handling children who are in conflict with the law.

Correctional Center, through the Community Counseling Officer (PK), are 
not only agencies assigned the task of conducting community research related to children involved in criminal cases as regulated in the Juvenile Court Law. However, through this Juvenile Criminal Justice System Law, Correctional Center is one of the important elements in the process of resolving criminal acts committed or involving children.

The Juvenile Criminal Justice System Law clearly and firmly stipulates the roles that must, even in some roles have a "mandatory" gradation, be carried out by the correctional center. The role carried out by the correctional center moves from the investigation stage to the stage of mentoring after serving a crime. However, the spirit contained in the The Juvenile Criminal Justice System Law is to prioritize efforts to restore justice (restorative justice) and prevent children from the judicial process (diversion). Therefore, Article 7 paragraph (1) states that at the level of investigation, prosecution, and examination of children's cases in district courts, it is obligatory to strive for diversion.

It should be understood that not all types of criminal acts can be diverted. This diversion is carried out in the event that a criminal act is committed: threatened with imprisonment under 7 (seven) years; and is not a repetition of a crime. If children's cases must be included in the judicial process, the Correctional Center (in this case the Community Counselor) or other assistant in accordance with the provisions of the legislation has the obligation to provide assistance to the children at every level of examination (see Article 23 paragraph (1).

Strengthening the role of the Correctional Center in the settlement of crimes committed by children is a strategy that can be developed so that the sanctions imposed on children who commit crimes truly fulfill a sense of justice.

A new alternative that is now being introduced in efforts to handle cases of juvenile crimes is to use a restorative justice approach. Restorative justice is a settlement process carried out outside the criminal justice system by involving victims, perpetrators, families of victims and perpetrators, the community and parties with an interest in a crime that occurred to reach an agreement and settlement.

The definition of restorative justice is explained in article 1 point 6 where Restorative Justice is the settlement of criminal cases by involving the perpetrator, 
victim, family of the perpetrator/victim, and other related parties together seek a fair solution by emphasizing restoration back to its original state, and not revenge. Handling conducted by taking into account the wider influence on victims, perpetrators and the community is conducted through a diversion mechanism.

The enactment of the Law of the Republic of Indonesia Number 11 of 2012 concerning the Juvenile Criminal Justice System at least provides a new nuance in handling children in conflict with the law. This law is considered capable of representing a restorative justice approach with a diversion mechanism. The diversion conducted in the juvenile criminal justice system law is conducted at every stage of the judicial process. This clearly will not be able to avoid the process of negative stigmatization of children because the process of stigmatizing children in conflict with the law begins when the children come into contact with the police.

The diversion process conducted in the prosecution and trial process is not able to avoid negative stigma against children because children have gone through the judicial process and even this process takes a long time and costs a lot of money. Therefore, it is necessary to reassess the placement of the diversion process in each stage of the juvenile criminal justice system and the significance of the use of warnings and informal diversion as a solution to avoid the high cost and lengthy process of implementing formal diversion.

Article 5 of Law Number 11 of 2012 concerning the Juvenile Criminal Justice System is a form of affirmation of the use of a restorative approach to the restorative justice model. In this article it is stated: (1) The Juvenile Criminal Justice System must prioritize the Restorative Justice approach. (2) The Juvenile Criminal Justice System as referred to in paragraph (1) includes: a. Criminal investigation and prosecution of children conducted in accordance with the provisions of the legislation, unless otherwise provided for in this law; b. children court session conducted by the court in the general court environment; and c. Mentoring, guidance, supervision, and/or assistance during the process of conducting a crime or action and after undergoing a crime or action. (3) In the Juvenile Criminal Justice System as referred to in paragraph (2) letters a and b, diversion must be sought. 


\section{The Nature of Transcendental Thought}

Kuntowijoyo interprets transcendental by basing faith in Allah (Ali Imron: 110) by introducing prophetic science, in the form of humanization (ta'muruna bil ma'ruf), liberation (tanhauna anil munkar) and transcendence (tu'minunabillah). In this case, the element of transcendence must be the basis of other elements in the development of science and human civilization. The method of developing science and religion according to Kuntowijoyo is called the prophetic term, based on the Qur'an and Sunnah, which is the main basis for the overall development of science. Qur'an and Sunnah are used as the basis for the entire building of prophetic science, both natural science (Kauniyah verse) as the basis for natural laws, (Nafsiyah verse) as the basis of meaning, value and awareness as well as divinity (Quliyah verse) as the basis of God's laws.

The transcendental dimension can be seen in the most basic teachings, namely aqidah which teaches an understanding of the relationship between humans and nature and with their God. Humans and nature are essentially mortal creatures, while God is the ruler of the universe and its contents (robbul alamin) which is eternal (baqa). The greatest happiness of a moslem is when he is able to completely surrender to Allah's natural commands (laws), whether general or detailed, as a consequence of his acknowledgment that Allah is One, the ruler of all, and all creatures depend on Allah

According to Ziauddin Sardar, the effort to rediscover Islamic science started from a rejection of the axioms about the universe, time, humanity and the goals of western science, and its methodology because western science has made a painful reduction of the objectification of nature and the painful torture of animals for an experiment with new scientific discoveries. Ziauddin Sardar wants an objective search for knowledge and is conducted as a form of worship whose position is the same as the daily form of worship as a moslem does in carrying out his obligations such as prayer, fasting, pilgrimage and other forms of worship.

From the perspective of transcendental jurisprudence, legal science is not only based on the truth at the level of haqq alyakin, which is compiled in the Qur'an and Hadith, but also based on the truth obtained with human potential abilities through contemplation, reasoning and discourse that develops in society. 
Humans explore, process and formulate knowledge with the aim not only for knowledge but also for policy, benefit the wider community, with the pleasure and love of Allah (Absori, 2015: 40-45).

Transcendental jurisprudence is begun in the will of Allah to His creatures who were sent down through His prophets and messengers, the prophets and saints who are always istiqomah and hold fast to the divine line (sunnahtullah). Sunnahtullah is the basis of the philosophy of natural law spelled out through His verses both written (the Book and the Sunnah) and those that are described in the universe and the reality of life.

Transcendental law is intended to guide human life to achieve happiness in the world and the hereafter. Transcendental law can only be understood with a holistic approach that sees humans and their lives in a complete form, not only material but also spiritual. Transcendental law can not be separated between the physical body (formal) and transcendental values. The only justification for transcendental law that is being pursued is for the sake of justice based on the truth of the power of Allah, the Almighty, the determinant of human life and life. Transcendental law is oriented to the benefit of humans as a form of compassion for their creatures (Absori, 2015: 40-45).

\section{Implementation of Transcendental Values in the Implementation of Juvenile Criminal Sanctions.}

In the Indonesian constitution, children have a strategic role which is explicitly stated that the state guarantees the rights of every child to survival, growth, and development as well as protection from violence and discrimination. The best interests of children should be considered as the best interests for the survival of mankind. The consequences of the provisions of Article 28B of the 1945 Indonesian Constitution need to be followed up by making government policies aimed at protecting children.

According to Darwan Prinst, children protection is a joint activity aimed at securing, procuring and fulfilling the physical and spiritual welfare of children in accordance with their interests and human rights (Darwan Prinst, 1997: 4). Arief Gosita said that providing protection to children or juvenile is something that is natural and is our responsibility. Protection for children from juvenile is none 
other than the goal is to ensure the welfare of children and juvenile and the protection of the interests of the childrenr can be achieved. All this must be done by all members of the community and is a shared responsibility (Arief Gosita, 1985: 226).

Crimes involving children as perpetrators of criminal acts are certainly not a new thing. Today there are many criminal incidents such as theft, mugging or extortion by a child. The limitation on children delinquency is emphasized against child perpetrators who are acts that violate the norm, but if it is done by adults, it is called a crime, because it feels unethical that child perpetrators are called “criminals” children but children delinquency because considering the children who commits the crime still needs supervision or coaching action (Nasriana, 2011: 29). So that in imposing sanctions for children who commit criminal acts, sanctions should be imposed on the background of coaching for children in the future by considering the sides that have aspects of humanism.

The imposition of humanitarian sanctions for children is deemed necessary because the future of children is still long. Legal treatment for children deserves serious attention because after all these children are the future of a nation. Therefore, in making decisions, judges must be sure that the decisions taken will be a strong basis for returning and regulating children towards a better future to develop themselves as citizens of the community who are responsible for the life of the nation (Nasriana, 2011: 68).

The renewal of sanctions for children who commit criminal acts has developed because the renewal of criminal law is based on and inspired by a strong and confident will and grows in a society that is in accordance with the philosophy of Pancasila and the 1945 Indonesian Constitution so that law enforcement in Indonesia is more humanistic in the future so that criminal law is able to satisfy all parties.

The implementation of transcendental values in imposing sanctions on children who commit crimes in the form of strengthening the imposition of verbal sanctions in the form of reprimands/warnings as an informal diversion mechanism aimed at children's interests so that children avoid negative stigma that can affect the children's future. The presence of the Juvenile Criminal Justice System Law, 
when examined substantively, will find the existence of transcendental legal thoughts in it. This can be understood by the existence of regulations regarding diversion, the application of restorative justice and the existence of verbal sanctions in the form of warnings or reprimands that are applied to children who commit crimes.

Children who commit criminal acts by the Juvenile Justice System Law are seen as God's creation as a whole, which has both good and bad sides. Crimes committed by children are not always purely the child's fault because children in carrying out any action still need guidance and supervision. Realizing this situation encourages the legislators to provide regulation on the Juvenile Criminal Justice System by incorporating transcendental values into it. This is in accordance with what the community wants that the purpose of the law should be able to bring benefits to mankind, especially for those who are experiencing legal problems.

Transcendental law in the Indonesian context cannot be separated from the basic principles contained in the state ideology, namely Pancasila. The core of Pancasila which consists of five precepts, in the form of divinity, humanity, unity, democracy and justice. According to the founding father of the nation, Soekarno, the core of Pancasila if it is compacted is in the form of mutual cooperation. In the legal field, the manifestation of the Pancasila ideology is embodied in the ideals of Pancasila law which serves as the foundation and direction of the development and development of national law. The ideals of Pancasila law are interpreted as rules of community behavior that are begun in the ideas, feelings, intentions, creativity and thoughts of the people themselves. In this case there are three elements, namely justice, usability and legal certainty. It is necessary to think about an approach that emphasizes a transcendental humanist approach to relation, which emphasizes the importance of good relations and prevents evil and divine control between parties or institutions, namely the existence of commitment and responsibility to God.

In the dynamics of community life, Pancasila as a legal ideal will function as a general guiding principle, a norm of criticism and a motivating factor in law enforcement (formation, discovery and application of law) and legal behavior. In 
this case the legal system is an exemplar of ramification of legal ideals into various legal rules that are arranged in a system. Therefore, the development and development of law should be based on and refer to legal ideals. By the founding fathers of the nation, Pancasila was placed as the philosophical foundation in arranging the basic framework and structure of the state organization. Pancasila is interpreted as a view of the nation's life that reveals the relationship between humans and God, humans and each other and humans with the universe which has a core belief about the place of individual humans in society and the universe.

\section{CONCLUSION}

Based on the description above, it can be concluded that the implementation of criminal sanctions for children as regulated in Law Number 11 of 2012 has adopted transcendental values or thoughts. The existence and implementation of the noble values of Pancasila as an inseparable part of transcendental thought is reflected in the implementation of diversion and restorative justice. In addition, the existence of the types of crimes regulated in Law Number 11 of 2012 which distances imprisonment and replaces it with criminal sanctions that are more humane to children is also proof that the application of criminal sanctions for children as regulated in Law Number 11 of 2012 has really implemented the value of -values or transcendental thought.

\section{REFERENCES}

Absori, Epistimologi Ilmu Hukum Transendental dan Implementasinya dalam Pengembangan Program Doktor Ilmu Hukum, 2015, Prosiding Seminar Nasional: ISBN 978-602-72446-0-3.

Arief, Barda Nawawi, 2003, Kapita Selekta Hukum Pidana, Bandung, Citra Aditya Bakti.

Arief, Gosita, 1985, Masalah Korban Kejahatan, Akademika Pressindo, Jakarta, Darwan Prinst. 1997. Hukum Anak Indonesia, Citra Aditya Bakti Bandung

Imron, Ali, 2015, Legal Responsibility: Membumikan Asas Hukum Islam Di Indonesia, Yogyakarta, Pustaka Pelajar.

Karim, M. Abdul, 2004, Menggali Muatan Pancasila Dalam Perspektif Islam, Yogyakarta, Sunan Kalijaga Press.

Lubis, M. Solly, dkk., 1995, Bunga Rampai Pembangunan Hukum di Indonesia, 
Bandung, Eresco.

Nasriana,2011, Perlindungan Hukum Pidana Bagi Anak di Indonesia, PT Raja Grafindo Persada, Jakarta

Noer, Deliar, 1980, Gerakan Modern Islam di Indonesia 1900-1942, Jakarta, LP3ES

Rahardjo, Satjipto, 2002, Sosiologi Hukum, Perkembangan Metode dan Pilihan Masalah, Surakarta, Muhammadiyah University Press.

Setiardja, Gunawan A., 1990, Dialektika Hukum dan Moral Dalam Pembangunan Masyarakat Indonesia, Yogyakarta, Kanisius

UU No. 11 tahun 2012, Tentang Sistem Peradilan Pidana Anak

Surat Edaran Makamah Agung Republik Indonesia (SEMA) No. 7 Tahun 1985

tentang Petunjuk Pelaksanaan Tugas Hakim Pengawas dan Pengamat

Surat Edaran Makamah Agung Republik Indonesia (SEMA) No. MA/Kumdil/31/I/2005 tanggal 11 Januari 2005 tentang Pengangkatan Hakim Anak

Putusan MK No. 1/PUU-VIII/2010 tentang penetapkan batas umur bagi anak untuk melindungi hak konstitusional anak terutama hak terhadap perlindungan dan hak untuk tumbuh dan berkembang 